\title{
Lack of effect of oral magnesium on high blood pressure: a double blind study
}

\author{
F P CAPPUCCIO, N D MARKANDU, G W BEYNON, A C SHORE, B SAMPSON, \\ G A MACGREGOR
}

\begin{abstract}
Seventeen unselected patients with mild to moderate essential hypertension and whose average supine blood pressure after two months' observation with no treatment was $154 / 100 \mathrm{~mm} \mathrm{Hg}$ were entered into a double blind randomised crossover study of one month's treatment with magnesium aspartate (15 mmol magnesium/day) and treatment with placebo for a further month. This preparation of magnesium was well tolerated and did not cause diarrhoea. Despite a significant increase in plasma magnesium concentration and a significant increase in urinary excretion of magnesium while taking magnesium aspartate there was no fall in blood pressure compared with either treatment with placebo or values before treatment. The results provide no evidence for a role of dietary magnesium in the regulation of high blood pressure and are contrary to recent speculations.
\end{abstract}

\section{Introduction}

In vitro, magnesium directly antagonises the effects of vasoactive substances on arteriolar smooth muscle ${ }^{12}$ and may be a "naturally occurring calcium antagonist." ${ }_{3}$ Parenteral magnesium was used to control convulsions and high blood pressure in acute glomerulonephritis ${ }^{4}$ and eclampsia, ${ }^{5}$ but it is not clear from

\footnotetext{
Blood Pressure Unit, Department of Medicine, and Department of Chemical Pathology, Charing Cross and Westminster Medical School, London W6 8RF

F P CAPPUCCIO, MD, clinical research fellow

N D MARKANDU, SRN, research assistant

$G$ W BEYNON, PHD, MRCP, clinical research fellow

A C SHORE, PHD, research assistant

B SAMPSON, MPHIL, MRSCCHEM, biochemist, department of chemical pathology

G A MACGREGOR, MA, FRCP, Wellcome senior lecturer

Correspondence to: Dr G A MacGregor.
}

these reports whether magnesium had a direct effect on blood pressure or whether the fall in blood pressure was due to a reduction in intracerebral pressure. Serum magnesium concentrations were found in one study to be lower in hypertensive patients than in normal subjects. ${ }^{6}$ The normal subjects, however, were younger than the hypertensive patients, and values widely overlapped. An inverse relation was found in normotensive elderly Danish subjects between serum magnesium concentrations and systolic blood pressure. ${ }^{7}$ Thiazide diuretics lower plasma magnesium concentrations during long term treatment. ${ }^{8}$ Recently, Dyckner et al found in an open study that supplementation with magnesium caused a further reduction in blood pressure in patients who were taking a thiazide diuretic. ${ }^{9}$

We therefore conducted a double blind randomised crossover study of supplementation with magnesium in untreated patients with mild to moderate essential hypertension.

\section{Patients and methods}

Patients referred by local general practitioners to the blood pressure unit were included in the study if, after two months' observation without treatment, their supine diastolic pressure was between 90 and $114 \mathrm{~mm} \mathrm{Hg}$ and no underlying cause for their high blood pressure had been found. Patients had either not previously received antihypertensive treatment or, if they had, it was stopped at least two months before the start of the study; treatment with thiazide diuretics was stopped at least three months before entry. Patients with renal failure (plasma creatinine concentration $>120 \mu \mathrm{mol} / 1(>1.4 \mathrm{mg}$ ) $100 \mathrm{ml}$ )), ischaemic heart disease, or cerebrovascular disease or who were taking the oral contraceptive pill or any other drug were excluded from the study. Seventeen patients who gave their informed consent entered and completed the study: nine were men and eight were women and 14 were white and three were black. Mean (range) age was $51 \cdot 7$ (33-66) years. Average supine blood pressure was $154 / 100$ $\mathrm{mm} \mathrm{Hg}$.

During the two month observation period before the study started patients were seen at the blood pressure unit every fortnight for measurements of blood pressures. At the end of this period blood pressure, pulse rate, weight, and two 24 hour measurements of urinary excretion of sodium, potassium, calcium, and magnesium were made. Blood was taken for measurement of urea, creatinine, 


\begin{tabular}{|c|c|c|c|c|c|}
\hline & \multirow[b]{2}{*}{ Before treatment } & \multicolumn{2}{|c|}{ Treatment with placebo } & \multicolumn{2}{|c|}{ Supplementation with magnesium } \\
\hline & & Second week & Fourth week & Second week & Fourth week \\
\hline $\begin{array}{l}\text { Lying blood pressure }(\mathrm{mm} \mathrm{Hg}) \\
\text { Standing blood pressure }(\mathrm{mm} \mathrm{Hg}) \\
\text { Weight }(\mathrm{kg}) \\
\text { Urinary sodium (mmol/24 h) } \\
\text { Urinary potassium }(\mathrm{mmol} / 24 \mathrm{~h}) \\
\text { Urinary magnesium }(\mathrm{mmol} / 24 \mathrm{~h}) \\
\text { Urinary calcium }(\mathrm{mmol} / 24 \mathrm{~h}) \\
\text { Plasma rerin activity }(\mathrm{mmol} / \mathrm{l} / \mathrm{h}) \\
\text { Plasma aldosterone }(\mathrm{pmol} / \mathrm{l}) \\
\text { Plasma magnesium }(\mathrm{mmol} / \mathrm{l}) \\
\text { Plasma calcium }(\mathrm{mmol} / \mathrm{l}) \\
\text { Serum ionised calcium }(\mathrm{mmol} / \mathrm{l})\end{array}$ & $\begin{array}{c}154 / 100(3 \cdot 1 / 1 \cdot 5) \\
156 / 106(3.8 / 1.9) \\
79 \cdot 0(4 \cdot 1) \\
138.2(6.9) \\
71.5(5) \\
4.75(0.26) \\
5.67(0.43) \\
1.12(0.25) \\
385(48) \\
0.89(0.02) \\
2.37(0.02) \\
1.27(0.02)\end{array}$ & $\begin{array}{c}156 / 100(3 \cdot 4 / 2 \cdot 3) \\
155 / 109(4 \cdot 6 / 2 \cdot 2) \\
78 \cdot 6(4) \\
126.3(11 \cdot 1) \\
74.6(5 \cdot 7) \\
4.66(0.48) \\
5.47(0.68)\end{array}$ & $\begin{array}{c}151 / 97(4.4 / 2) \\
154 / 106(4 \cdot 4 / 1 \cdot 8) \\
78.3(4) \\
147.9(17.9) \\
70.9(6.8) \\
4.62(0.47) \\
5.76(0.77) \\
1.07(0.25) \\
403(37) \\
0.86(0.02) \\
2.33(0.02) \\
1.28(0.02)\end{array}$ & $\begin{array}{c}154 / 98(3 \cdot 3 / 2 \cdot 3) \\
155 / 107(5 / 1 \cdot 9) \\
78 \cdot 7(4) \\
142 \cdot 8(11 \cdot 9) \\
78 \cdot 3(4 \cdot 6) \\
6.62(0.48)^{* * *} \\
6 \cdot 12(0 \cdot 6)\end{array}$ & $\begin{array}{l}154 / 98(3 \cdot 4 / 2 \cdot 2) \\
157 / 105(4 \cdot 3 / 1 \cdot 9) \\
78 \cdot 4(4 \cdot 1) \\
134(12 \cdot 2) \\
73.9(4 \cdot 8) \\
6.36(0 \cdot 46)^{* * *} \\
6.31(0 \cdot 66) \\
1.27(0.38) \\
387(44) \\
0.91(0.02)^{* *} \\
2.33(0.02) \\
1.27(0.02)\end{array}$ \\
\hline
\end{tabular}

${ }^{* *} \mathrm{p}<0.02 ; * * * \mathrm{p}<0.001$ for differences between effects of magnesium and placebo.

$24 \mathrm{mg} / 24 \mathrm{~h}$ Urinary $2.4 \mathrm{mg} / 100 \mathrm{ml}$. Plasma calcium: $1 \mathrm{mmol} / \mathrm{l} \approx 4 \mathrm{mg} / 100 \mathrm{ml}$.

sodium, potassium, magnesium, total and ionised calcium, and aldosterone concentrations and plasma renin activity. Patients were then entered into a double blind randomised crossover study of one month's treatment with magnesium aspartate hydrochloride $15 \mathrm{mmol}$ daily given in the form of two tablets three times daily (Magnesiocard, Verla) and one month's treatment with matching placebo tablets. Patients did not alter their diet either before or during the study. Nine patients were given magnesium first and eight placebo.

During the trial measurements of blood pressures were taken fortnightly. Each patient was seen on the same day of the week, at the same time of day, by the same nurse, and in the same room. Blood pressure was measured in the same arm by nurses using semiautomatic ultrasound sphygmomanometers (Arteriosonde) ${ }^{10}$ with attached recorders. Measurements were therefore free from observer bias. Supine and standing blood pressures were the means of five readings taken every one to two minutes. Pulse rate was measured by a pulse monitor (Cambridge 3048). At the second, fourth, sixth, and eighth weeks of the trial two 24 hour samples of urine were collected, and blood was also taken for measurement of urea, creatinine, plasma sodium, potassium, magnesium, total and ionised calcium, and aldosterone concentrations and plasma renin activity. The mean of two 24 hour urinary estimations was taken as the urinary excretion of sodium, potassium, magnesium, and calcium at the time. Blood samples were taken without stasis after the patient had been sitting upright for 10 minutes some time between 10 am and 12 noon. To measure ionised calcium concentrations $10 \mathrm{ml}$ blood was taken anaerobically in plain glass tubes. Serum ionised calcium concentration was measured with a Kone microlyte ion selective electrode analyser, and $\mathrm{pH}$ of the same sample was measured with a Corning $\mathrm{pH}$ meter. Plasma magnesium concentration was measured by the calmagite dye binding method. Urinary excretion of magnesium was measured by atomic absorption spectroscopy after dilution with lanthanum chloride and n-butanol. Plasma renin activity and aldosterone concentration were measured by radioimmunoassay. ${ }^{11} 12$

Mean arterial pressure was calculated by adding one third of the pulse pressure to the diastolic pressure. Results are reported as means (SEM). Statistical analysis was performed by paired Student's $t$ tests and simple correlation analyses by the University of London's computer and the north western universities' statistical package for the social sciences. Measurements of blood pressure from the period of treatment with placebo and that of supplementation with magnesium were used to estimate the within individual variance of change in blood pressure between periods. ${ }^{13} \mathrm{~W}$ ith a sample size of 17 and by the use of the two tailed $t$ test the study had a power of $90 \%$ to detect an $8 / 6 \mathrm{~mm} \mathrm{Hg}$ change in blood pressure at the $5 \%$ level.

\section{Results}

After two and four weeks of supplementation with magnesium there was no significant change in either systolic or diastolic pressure compared with equivalent blood pressures after treatment with placebo or pressures before treatment (fig 1). Changes in standing blood pressure were similar to those in supine blood pressure (table).

Mean urinary excretion of magnesium increased from $4.66(0.48)$ $\mathrm{mmol} / 24 \mathrm{~h}(113.4(11.7) \mathrm{mg} / 24 \mathrm{~h})$ in the second week of treatment with placebo to $6.62(0.48) \mathrm{mmol} / 24 \mathrm{~h}(160.9(11.7) \mathrm{mg} / 24 \mathrm{~h})$ in the second week of supplementation with magnesium (a mean increase in excretion of magnesium of $1.96 \mathrm{mmol} / 24 \mathrm{~h}(47.6 \mathrm{mg} / 24 \mathrm{~h} ; \vec{\circ}$ $\mathrm{p}<0.001)$ ) and from $4.62(0.47) \mathrm{mmol} / 24 \mathrm{~h}(112.3(11.4) \mathrm{mg} / 24 \mathrm{~h}) \vec{\omega}$ in the fourth week of treatment with placebo to $6.36(0.46) \mathrm{mmol} / 24 \mathrm{~h}$. $(154.6(11.2) \mathrm{mg} / 24 \mathrm{~h})$ in the fourth week of supplementation with $\frac{5}{3}$

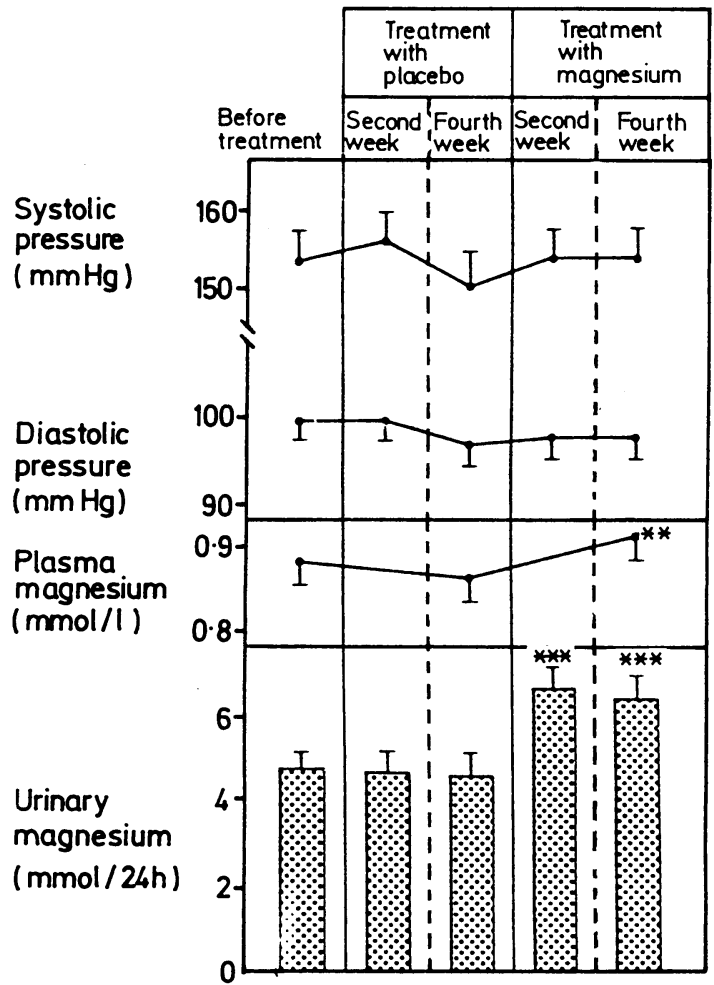

FIG 1-Average systolic and diastolic blood pressures, plasma magnesium concentrations, and urinary excretion of magnesium before and during treatment with magnesium and placebo. ${ }^{* *} p<0.02 ;{ }^{* *} p<0.001$ for differences between treatment with magnesium and placebo. Bars represent means and SEM.

Conversion: SI to traditional units-Plasma magnesium: $1 \mathrm{mmol} / 1 \approx 2.4 \mathrm{mg} / 100 \mathrm{ml}$. Urinary magnesium: $1 \mathrm{mmol} /$ $24 \mathrm{~h} \approx 24 \mathrm{mg} / 24 \mathrm{~h}$.

magnesium (a mean increase in excretion of magnesium of $1.74 \frac{0}{0}$ $\mathrm{mmol} / 24 \mathrm{~h}(42.3 \mathrm{mg} / 24 \mathrm{~h} ; \mathrm{p}<0.001))($ fig 1$)$. No difference was seen $\overrightarrow{\mathbb{D}}$ between urinary excretion of magnesium on entry to the study and $\stackrel{?}{\odot}$ while treated with placebo (fig 1). Fourteen out of 17 patients had $\stackrel{\mathbb{Q}}{\varrho}$ an increase in urinary excretion of magnesium during the fourth $\bar{\sigma}$ week of supplementation with magnesium compared with the fourth $ᄋ$ week of treatment with placebo (fig 2). The 24 hour urinary excretion 0 of calcium was increased during supplementation with magnesium, but the difference was not significant (table).

Plasma magnesium concentrations increased from $0.86(0.02) \risingdotseq$ $\mathrm{mmol} / \mathrm{l}(2 \cdot 1(0 \cdot 05) \mathrm{mg} / 100 \mathrm{ml})$ by the fourth week of treatment with 
placebo to $0.91(0.02) \mathrm{mmol} / 1(2.2(0.05) \mathrm{mg} / 100 \mathrm{ml})$ by the fourth week of supplementation with magnesium, a mean increase of $0.05 \mathrm{mmol} / 1(0.12 \mathrm{mg} / 100 \mathrm{ml})$ or $6 \%(\mathrm{p}<0.02)$. Total plasma sodium, potassium, urea, and creatinine concentrations did not alter. Serum ionised calcium concentrations did not change even when corrected for $\mathrm{pH}$. There was no significant change in weight during the periods of treatment with placebo and magnesium (table).

Eight of the 17 patients had low plasma renin activity for their excretion of sodium. The nine other patients had normal values of plasma renin activity. Plasma magnesium and serum ionised calcium concentrations before entry to the study were not different in these two groups of patients. When supplemented with magnesium there was no significant change in either plasma renin activity or plasma aldosterone concentration compared with values obtained when treated with placebo (table).

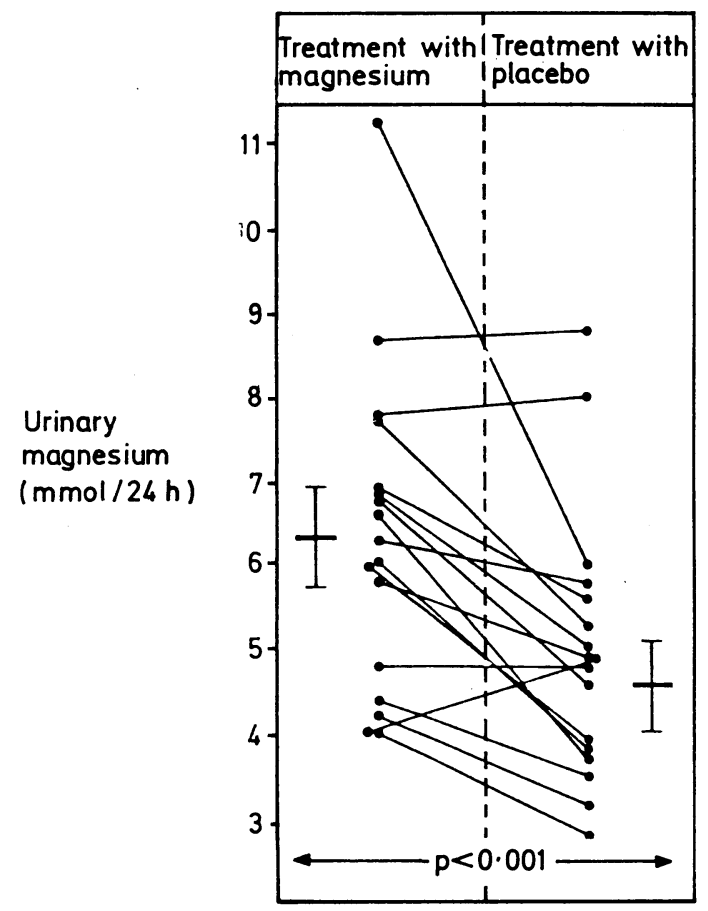

FIG 2-Changes in $24 \mathrm{~h}$ urinary excretion of magnesium between the fourth week of treatment with placebo and with magnesium. Bars represent means and SEM.

Conversion: SI to traditional units-Urinary magnesium: $1 \mathrm{mmol} / 24 \mathrm{~h} \approx 24 \mathrm{mg} / 24 \mathrm{~h}$

Eight patients had a decrease in blood pressure when the fourth week of supplementation with magnesium was compared with that of placebo, whereas nine had no change or an increase in blood pressure (fig 3). This difference in response to supplementation with magnesium, whether expressed as an absolute or percentage change in blood pressure, was not related significantly to order of treatment; age; race; sex; plasma renin activity, aldosterone concentration, or excretion of sodium, potassium, magnesium, and calcium before treatment; and increase in excretion of magnesium and plasma magnesium concentration. All patients who entered the trial completed it without any adverse effects, and no patients complained of diarrhoea. Supplementation with magnesium was not continued after the end of the trial.

\section{Discussion}

Our findings show that in untreated patients with mild to moderate essential hypertension a roughly twofold increase in the intake of magnesium for one month given as aspartate hydrochloride (15 mmol magnesium daily) did not cause any change in blood pressure. This form of supplementation with magnesium was well absorbed, and patients' compliance with the supplementation was good, as shown by the significant increase in urinary excretion of magnesium and the significant increase in plasma magnesium concentration that occurred compared with treatment with placebo. These results contrast with those of an uncontrolled study by Dyckner et al in which a similar amount of magnesium aspartate was given to patients who were already being treated with thiazide diuretics and who tended to have plasma magnesium concentrations below the normal range. ${ }^{9} \mathrm{~A}$ significant additional fall in blood pressure of $12 / 8 \mathrm{~mm} \mathrm{Hg}$ was reported despite no significant increase in plasma magnesium concentration or urinary excretion of magnesium. As the control group in this study did not receive placebo no definite conclusions can be drawn about the effect of supplementation with magnesium in lowering blood pressure even during treatment with diuretics.

Resnick et al reported that serum magnesium concentrations may be reduced in patients with high renin hypertension, ${ }^{14}$ although, overall, there was no difference in serum magnesium concentrations between patients with hypertension and normotensive subjects. We found no difference in plasma magnesium concentrations between patients with low plasma renin activity and those with normal plasma renin activity. In particular, there was no significant correlation between changes in blood pressure

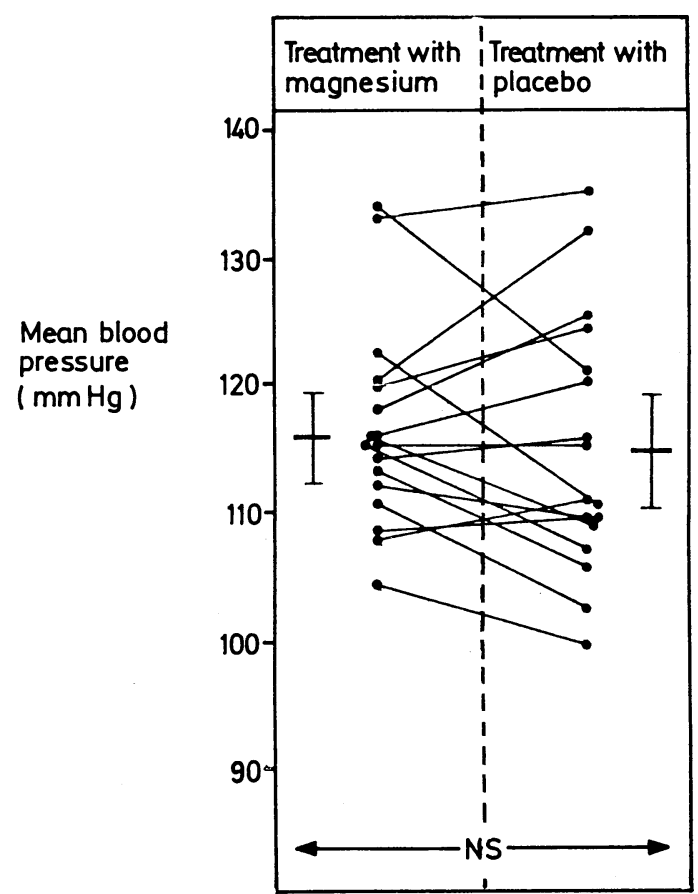

FIG 3-Changes in mean supine blood pressure between the fourth week of treatment with placebo and with magnesium. Bars represent means and SEM.

with supplementation with magnesium and initial plasma renin activity.

Serum magnesium concentration has been claimed to be inversely related to blood pressure. ${ }^{67}$ Kesteloot, however, could not show any significant relation between 24 hour urinary excretion of magnesium and blood pressure in a population sample in Korea. ${ }^{15}$ Epidemiological studies have shown a higher incidence of cardiovascular disease in geographical areas with soft drinking water supplies or soil deficient in magnesium. ${ }^{16-20}$ Magnesium is widely distributed in food, and unless there were problems with absorption or increased excretion ${ }^{2122}$ it would be difficult to become deficient in magnesium with a normal Western diet.

In vitro experiments have shown that extracellular magnesium plays a critical part in the regulation of the reactivity of smooth muscle cells. ${ }^{2}$ For example, lowering the extracellular 
magnesium concentration to between 0.2 and $0.6 \mathrm{mmol} / 1$ $(0.5$ and $1.5 \mathrm{mg} / 100 \mathrm{ml})$ increased the reactivity of isolated aortic strips of rats to various vasoactive agents. ${ }^{23}$ Similarly, experiments in rats maintained for 12 weeks with a diet that was moderately or severely deficient in magnesium showed significant increases in arterial blood pressure compared with control animals. ${ }^{24}$ Serum magnesium concentrations, however, were approximately 30 and $70 \%$ lower, respectively, than in the control animals, and this reduction in serum magnesium concentration is unlikely to occur in patients with untreated essential hypertension.

In our study supplementation with magnesium was for one month only and therefore no definite conclusions can be drawn about any longer term effects of supplementation with magnesium on high blood pressure. During one month, however, despite a significant increase in plasma magnesium concentration there was no decrease in blood pressure, suggesting that when plasma magnesium concentration is in the normal range supplementation of the diet with magnesium has little or no effect on blood pressure. Magnesium given as aspartate was well tolerated and did not cause any gastrointestinal problems: it would be a useful way of giving magnesium in further studies and when deficiency in magnesium is known to occur-for example, during treatment with some cytotoxic drugs. ${ }^{25} 26$

\section{References}

1 Altura, BM, Altura BT. Magnesium and contraction of arterial smooth muscle. Microvasc Res 1974;7:145-55.

ium ins in contractility of blood vessels and skeletal muscles. Magnesium Bulletin 1981;1:102-14.

$3 \mathrm{Kesteloot} \mathrm{H}$. Epidemiological studies on the relationship between sodium, potassium, calcium and magnesium and arterial blood pressure. $\mathcal{f}$ Cardiovasc Pharmacol 1984;6 (suppl):192-6.
4 Blackfan KD, Hamilton B. Uremia in acute glomerular nephritis. Boston Medical and Surgical fournal 1925;193:617-29.

5 Stieglitz EJ. M Fishbein, ed. Abnormal arte Medical Book Company Inc, 1935:165-6. essential vascular hypertension. Circulation 1958;17:761-4

7 Petersen B, Schroll M, Christiansen C, Transbol I. Serum and erythrocyte magnesium in normal elderly Danish people. Acta Med Scand 1977;201:31-4. for heart failure. $B r$ Med $\mathcal{F}_{1972 ; \text { iii:620-2. }}$.

Dyckner T, Wester PO. Effect of magnesium on blood pressure. Br Med $f$

10 George CF, Lewis PJ, Petrie A. Clinical experience with the use of an ultrasound sphygmomameter. Br Heart $\mathcal{f} 1975 ; 37: 804-7$.

Roulston JE, MacGregor GA. Measurement of plasma renin activity by radio immunoassay after prolonged cold storage. Clin Chim Acta 1978;88:45-8.

12 James VHT, Wilson GA. Determination of aldosterone in biological fiuids. In: Reid E, ed. Assay of drugs and other trace compounds in biological fiudsmethodological development in biochemistry. Vol 5. Amsterdam: Elsevier, 1976:149-58.

13 Bulpitt CJ. Randomised controlled clinical trials. The Hague, Boston, London: Martinus Nijhoff Publishers, 1983:96-117.

14 Resnick LM, Laragh JH, Sealey JE, Alderman MH. Divalent cations in essentia hypertension. N Engl $f$ Med $1983 ; 309: 888-91$.

15 Kesteloot H, Geboers J, Van Hoof R. Epidemiological study of the relationship between calcium and blood pressure. Hypertension 1983;5(suppl ii):52-6.

16 Crawford T, Crawford MD. Prevalence and pathological changes of ischaemic heart disease in a hard-water and in a soft-water area. Lancet 1967;1:229-32. supplies, Lancet $1968 ; \mathrm{i}: 827-31$

8 Anderson TW, Leriche WH, Mackay JS. Sudden death and ischaemic heart disease-correlation with hardness of local water supply. $N$ Engl $f$ Med 1969;280:805-7.

19 Dawson EB, Frey MJ, Moore TD, McGarity WJ. Relationship of meta metabolism to vascular disease mortality rates in Texas. Am $\mathcal{f}$ Clin Nut $1978 ; 31: 1188-97$.

20 Karpanen H, Pennanen R, Passinen L. Minerals, coronary heart disease and sudden coronary death. Adv Cardiol 1978;25:9-24

21 Nordin BEC. Calcium, phosphate and magnesium metabolism. Edinburgh, London, New York: Churchill Livingstone, 1976:26-9.

22 Agus ZS, Wasserstein A, Goldfarb S. Disorders of calcium and magnesium homeostasis. Am 7 Med 1982;72:473-88.

23 Altura BM, Altura BT. Magnesium ions and contractions of vascular smooth muscles: relationship to some vascular diseases. Fed Proc 1981;40:2672-9.

24 Altura BM, Altura BT, Gebrewold A, Ising H, Gunther T. Magnesium deficiency and hypertension: correlation between magnesium-defic

25 Schilsky RL, Anderson T. Hypomagnesemia and renal magnesium wasting in patients receiving asplatin. Ann Intern Med 1979;90:929-31.

26 Lyman NW, Hemaletha C, Viscuso RL, Jacobs MG. Asplatin-induced hypocalcemia and hypomagnesemia. Arch Intern Med 1980;140:1513-4.

(Accepted 2 April 1985)

\section{YEARS AGO}

The Medical Department of the Local Government Board has not been slow to set in motion the special series of sanitary inspections which, after much persuasion, the Treasury lately gave them the means of undertaking. Dr. Buchanan could not afford to lose much time, for we believe the temporary strengthening of his busy department has only been sanctioned for one year. Roughly speaking, the work has been divided into two classes-visitation of all ports and sea-board districts, and inspection of such inland places as seem to have been most neglected, or likely to profit most by timely advice. Work already in hand by the permanent medical staff has, to save time, been made to fit in, as far as possible, with the new arrangements. The inspection of ports has, for obvious reasons, been pressed forward with special energy; and there are now but few sea-board towns and districts that have not been visited by Dr. Blaxall, Professor de Chaumont, or Dr. Davies, and about which the Central Board have not full information. Sanitary administration at some of our ports is by no means as perfect and complete as it should be, and thus the Government Inspectors have had opportunities of giving valuable advice at their conferences with the local authorities and officials, and of pointing out the directions in which the sanitary defences of the several districts can be strengthened. The purity and quantity of the watersupplies; the efficiency of the sewerage-systems and of the arrangements for removing and disposing of the refuse, etc.; whether adequate hospitalaccommodation and arrangements for disinfecting clothing, etc., have been provided, or are available at a moment's notice; whether the arrangements for supervising and inspecting the shipping entering the port are sufficient; all these, and many other points, have, in a more or less general way, been investigated by the inspectors. As regards the inland districts, the inspectors, besides dealing with the larger questions of drainage, watersupply, and hospital-provision, note the condition of the dwellings of the poor, the state of slaughter-houses, of dairies, cowsheds, and milkshops, the prevalent method of feeding young infants, the influence on health of the ordinary industries in the district, and whether poverty prevails to any extent. The working and influence of the Canal Boats Acts are also specially looked into. The apprehension of cholera invading this country during the present year is an useful and legitimate lever, with which to move lethargic sanitary authorities and householders to appreciate the unwholesomeness of many of their ordinary surroundings; and the counsel of the inspectors will no doubt often stimulate wavering authorities to decide upon carrying out much needed sanitary improvements, that have been shelved under the false sense of security induced by the absence of epidemic disease. We feel sure that a very useful work, at present difficult of measurement, is in progress, and that when the report of the "sanitary survey" comes to be published, the Treasury and the public will be satisfied that the money spent on it has been well laid out. (British Medical Fournal 1885;i:957.)

Among the minor evils of town life, few things are occasionally more annoying to the Englishman than the almost complete absence of public lavatory accommodation. He cannot help feeling that the English habits of decency and reserve must either occasionally break down entirely, or else lead to discomfort, sometimes deepening into suffering, and now and then laying the foundation for serious injury to health. There is so much sobe truth in this, and there is no excuse for not taking practical action. We have been very glad to see that a Public Lavatory Committee of the Vestry of Paddington, under the presidency of $\mathrm{Mr}$. Mark $\mathrm{H}$. Judge, has presented a report to the vestry on the insufficiency of their public accommodation; "it is exclusively for men, and consists simply of eleven urinals," many of which are very badly placed, in addition to scanty and improper resorts in connection with public-houses. The committee points out that the vestry has the power, under the Paddington Local Act of 1824, to order the keepers of the public-houses to set up such places of convenience as the vestry may direct, and they recommend that each licensed victualler should be required to do so in a proper fashion; and further, that two public lavatories should be set up at the expense of the vestry, one of which should be adapted in part for women, and have a lavatory-attendant, whose expenses might be defrayed by a very small charge for the use of the closets and wash-basins. That the convenience of the women should not be neglected, is a matter of considerable importance; and we hope it may be duly attended to in any plan which may be carried out, for the management of the matter to such a large extent by the public-houses is certainly not an ideal arrangement for the men, and quite inadmissible for the women, though it may be the one most readily attainable, and much better than nothing. (British Medical Fournal 1885;i:1168.) 